\title{
The Contribution of Skin Glycosaminoglycans to the Regulation of Sodium Homeostasis in Rats
}

\author{
D. SUGÁR ${ }^{1}$, R. AGÓCS ${ }^{1}$, E. TATÁR ${ }^{2}$, G. TÓTH ${ }^{3}$, P. HORVÁTH ${ }^{3}$, E. SULYOK ${ }^{4}$, \\ A. J. SZABÓ ${ }^{1,5}$
}

${ }^{1}$ First Department of Pediatrics, Research Laboratory, Semmelweis University, Budapest, Hungary, ${ }^{2}$ Institute of Chemistry, Faculty of Science, Eötvös Loránd University, Budapest, Hungary, ${ }^{3}$ Department of Pharmaceutical Chemistry, Semmelweis University, Budapest, Hungary, ${ }^{4}$ Faculty of Health Sciences, University of Pécs, Pécs, Hungary, ${ }^{5}$ HAS-SE Nephrology Research Laboratory, Budapest, Hungary

Received August 10, 2016

Accepted March 31, 2017

On-line July 18, 2017

\section{Summary}

The glycosaminoglycan (GAG) molecules are a group of high molecular weight, negatively charged polysaccharides present abundantly in the mammalian organism. By their virtue of ion and water binding capacity, they may affect the redistribution of body fluids and ultimately the blood pressure. Data from the literature suggests that the mitogens Vascular Endothelial Growth Factor (VEGF)-A and VEGF-C are able to regulate the amount and charge density of GAGs and their detachment from the cell surface. Based on these findings we investigated the relationship between the level of dietary sodium intake, the expression levels of VEGF-A and VEGF-C, and the amount of the skin GAGs hyaluronic acid and chondroitin sulfate in an in vivo rat model. Significant correlation between dietary sodium intake, skin sodium levels and GAG content was found. We confirmed the GAG synthesizing role of VEGF-C but failed to prove that GAGs are degraded by VEGF-A. No significant difference in blood pressure was registered between the different dietary groups. A quotient calculated form the ion and water content of the skin tissue samples suggests that - in contrast to previous findings the osmotically inactive ions and bound water fractions are proportional.

\section{Key words}

Glycosaminoglycans • Sodium • Body fluids • Blood pressure • Vascular Endothelial Growth Factor

\section{Corresponding author}

A. J. Szabó, First Department of Pediatrics, Semmelweis University, 1083 Budapest, Bókay János u. 53-54., Budapest, Hungary. Fax: +36-1-3036077. E-mail: attila.szabo@med.semmelweis.univ.hu

\section{Introduction}

Recent experimental data have suggested that in addition to the kidney local tissue regulation of sodium and volume by the skeletal muscle, the bone and the skin is of great importance as these tissues are able to store and release significant amounts of sodium. A number of previous studies (Heer et al. 2000, Palacios et al. 2004, Titze et al. 2002a) reported on the short term changes in volume of body fluid compartments following $\mathrm{Na}^{+}$ingestion: increment in total body mass as well as body fluid content were observed.

Heer et al. (2000) were the first to demonstrate that the rise in total body sodium content is not necessarily paralleled by commensurate water retention. The same conclusion was drawn by other research groups (Palacios et al. 2004, Titze et al. 2002b) It has also been proved that the excretion of sodium through urine, stool and sweat does not match the amount of the ingested sodium, suggesting a water free storage of the excess sodium (Heer et al. 2000, Palacios et al. 2004). Seeliger and his colleagues (Seeliger et al. 2006) criticized these 
results, stating that water-free sodium storage is more likely to be an intracellular mechanism. Data from further examinations (Heer et al. 2009, Schafflhuber et al. 2007) have shown that the mechanism in question accounts only for the $22 \%$ of $\mathrm{Na}^{+}$to remain in the body. The rest $(78 \%)$ is presumably stored in an osmotically inactive manner in the EC compartment.

Based on these experimental data and clinical observations it became evident that there is not a close link between the total sodium content of the body and the volume of different water compartments in the long term. Given that the above mentioned intracellular $\mathrm{Na}^{+} / \mathrm{K}^{+}$ exchange only partially accounts for the storage of excess sodium and that the sodium concentration of the serum remained in the normal physiological range during salt overload, it is presumable that considerable sodium reservoirs exist in the mammalian organism. Animal experiments conducted on salt sensitive and salt resistant rat strains supported the sodium buffering role of the hypothesized sodium reservoirs (Titze et al. 2002a). Further animal experiments (Titze et al. 2002a, Titze et al. 2003) determined the location of these osmotically inactive reservoirs: the majority of the excess sodium is stored in the skin, and only a smaller fraction is located in the bone, the cartilage and the skeletal muscle (Sulyok 2006) The presence of osmotically inactive sodium storages have also been confirmed applying ${ }^{23} \mathrm{Na}$ and ${ }^{1} \mathrm{H}$ MR techniques in humans in vivo (Dahlmann et al. 2015, Kopp et al. 2013, Kopp et al. 2012, Linz et al. 2015).

Sodium in the skin is bound to negatively charged macromolecules, predominantly to glycosaminoglycans (GAGs). GAGs are nitrogen containing molecules made up of repeated dimers. The most common GAGs of the body are hyaluronic acid, heparin sulfate, chondroitin sulfate and dermatan sulfate. It has also been shown that the total content, charge density and polymerization of GAGs correlates with the extremes in dietary sodium intake (Farber et al. 1957, Machnik et al. 2009, Titze et al. 2004). Titze et al. (2009) proposed a regulating cascade in which increased subcutaneous sodium modulates lymphangiogenesis and blood pressure (Machnik et al. 2009). Macrophages accumulating in the subcutaneous compartment sense hypertonicity and facilitate lymph capillary hyperplasia via Vascular Endothelial Growth Factor-C (VEGF-C) secretion. Increased lymph capillaries temporarily store the interstitial fluid and blunt blood pressure response to high salt.

This concept does not provide information about the mechanism by which this uniquely bound sodium is released and drained back to the circulation. (Foster et al. 2013) provided evidences that two isoforms of Vascular Endothelial Growth Factor, VEGF-A and VEGF-C regulate the amount and charge density of the glycocalyx of conditionally immortalized glomerular endothelial cells of the kidney podocytes. Based on these results, we attempted to define the role of skin GAGs in the regulation of body sodium homeostasis. We wanted to investigate, whether this regulated synthesis and degradation of GAG molecules is also present in the skin, and whether this phenomenon plays significant role in the regulation of skin sodium levels.

\section{Methods}

Animals

8-week-old female Wistar rats (weight 180-200 g) were purchased from Toxi-Coop Ltd. (Dunakeszi, Hungary). All experimental protocols were approved by the Committee on the Care and Use of Laboratory Animals of the Council on Animal Care at the Semmelweis University of Budapest, Hungary (TUKEB 380/2013).

\section{Treatment groups}

In all experiments two types of dietary regimes were applied: low salt diet (LSD) consisted of a virtually sodium free $(\mathrm{NaCl}<0.03 \% \mathrm{~m} / \mathrm{m})$ rat chow (E 15430-24; Ssniff Gmbh, Soest, Germany) and tap water to drink. High salt diet (HSD) consisted of a sodium rich $(\mathrm{NaCl}=8 \% \mathrm{~m} / \mathrm{m})$ rat chow and $0.9 \%$ saline as drinking water (treatment groups are summarized in Table 1).

In Experiment 1, 24 rats after one week of standard diet were randomly assigned to three groups. Group LSD $(\mathrm{n}=8)$ received a low salt diet for 4 weeks. Group HSD $(n=8)$ received a high salt diet for 4 weeks. Group HSD/LSD $(n=8)$ received a high salt diet for 4 weeks followed by a low salt diet for another 4 weeks.

In Experiment 2, 24 female Wistar rats after one week of standard diet were randomly assigned to two groups. Group LSD $(n=12)$ received a low salt diet for 4 weeks. Group HSD $(n=12)$ received a high salt diet for 4 weeks.

In Experiment 3, 12 female Wistar rats after one week of standard diet were kept on a high salt diet for four weeks followed by a $72 \mathrm{~h}$ period of low salt diet. The animals were kept under standard laboratory conditions with free access to the respective rodent chow and drinking water. 
Table 1. Description of treatment groups.

\begin{tabular}{|c|c|c|c|c|c|c|}
\hline & \multicolumn{2}{|c|}{ Experiment 1} & \multicolumn{2}{|c|}{ Experiment 2} & \multicolumn{2}{|c|}{ Experiment 3} \\
\hline Species/Strain & \multicolumn{6}{|c|}{ Rattus norvegicus/Wistar } \\
\hline Gender/Age & \multicolumn{6}{|c|}{ Female/8-week old } \\
\hline Treatment groups & LSD & HSD & HSD/LSD & LSD & HSD & $\mathrm{HSD} / \mathrm{LSD}$ \\
\hline Sample size (n) & 8 & 8 & 8 & 12 & 12 & 12 \\
\hline Time span of the & \multicolumn{6}{|c|}{ After 1 week of standard diet } \\
\hline experiment & 4 weeks & 4 weeks & $4+4$ weeks & 4 weeks & 4 weeks & 4 weeks $+72 \mathrm{~h}$ \\
\hline
\end{tabular}

Abbreviations: LSD - low salt diet, HSD - high salt diet, HSD/LSD - high salt diet followed by low salt diet.

\section{Body weight measurement}

Body weight of the animals was measured every week during the whole experimental period.

\section{Blood pressure measurement}

In Experiments 2 and 3 arterial blood pressure (systolic, diastolic, mean (MAP)) was measured with Coda (Kent Scientific Corporation, Torrington, USA) non-invasive digital blood pressure monitor. Blood pressure was measured on the tail arteries of conscious animals. Measurements were performed once every week during the whole experimental period.

\section{Blood, urine and skin sampling}

At the end of the experiments the animals were anesthetized using intraperitoneal Ketamine-Xylazine injection, and blood samples $(5 \mathrm{ml})$ were taken from the right cardiac ventricle before the animals were killed. We obtained urine samples by bladder puncture. The carcasses were skinned to provide tissue samples for biochemical and chemical analyses and for the determination of gene expression levels.

\section{Determination of ions, creatinine and urea in serum and} urine

The $\mathrm{Na}^{+}, \mathrm{K}^{+}, \mathrm{Cl}^{-}$, creatinine and urea content of the blood and the urine samples was analysed with a Beckman Coulter AU480 Chemistry System.

\section{Determination of skin water content}

In Experiment 2 the skin samples were weighed (wet weight) and then desiccated at $90^{\circ} \mathrm{C}$ for $72 \mathrm{~h}$ (dry weight). Because further drying left weights unchanged, the difference between wet weight and dry weight was considered as tissue water content.

\section{Determination of skin $\mathrm{Na}+$ and $\mathrm{K}+$ content}

In Experiment 1 and Experiment 2 skin samples were frozen by liquid nitrogen and pulverized mechanically with a commercially available coffee grinder. Thereafter 1 gram of the raw (Experiment 1) or the desiccated (Experiment 2) skin samples were dissolved in $5 \mathrm{ml} \mathrm{HNO}_{3}$ overnight followed by adding $3 \mathrm{ml} \mathrm{H}_{2} \mathrm{O}_{2}$ $(30 \%)$ to it. Samples were digested using microwave heated teflon bombs. Homogenized samples were diluted to a final volume of $25 \mathrm{ml}$ and filtered through a $0.45 \mu \mathrm{m}$ pore size syringe filter. $\mathrm{Na}^{+}$and $\mathrm{K}^{+}$concentrations in the solutions were measured with a PFP7 type flame photometer (Buck Scientific, Norwalk, USA). In order to eliminate eventual disturbances which ionization may cause, separate series of dilution were made to calibrate $\mathrm{Na}^{+}$and $\mathrm{K}^{+}$content. Every time, to the standard series of dilution the standard of the other alkali metal was added in a concentration as the sample to be measured it required (Chen et al. 2005, Dipietro et al. 1988).

\section{Glycosaminoglycan disaccharide analysis}

We cut $0.5 \mathrm{~g}$ of skin, taken from the left scapula angulus inferior from rats into small slices and digested with $7.0 \mathrm{mg}$ proteinase K (Sigma-Aldrich, Taufkirchen, Germany) in $10 \mathrm{ml} 20 \mathrm{mM}$ Tris-buffer ( $\mathrm{pH} \mathrm{7.0)}$ at $55^{\circ} \mathrm{C}$ for $16 \mathrm{~h}$. The reaction was blocked by boiling the solution for $5 \mathrm{~min}$. After centrifugation, we added $100 \mathrm{ml}$ acetone to the supernatant and stored the tubes at $-20^{\circ} \mathrm{C}$ for $16 \mathrm{~h}$. After precipitation, the tubes were centrifuged at 4,000 rpm for $5 \mathrm{~min}$ and the precipitate was dried at $90{ }^{\circ} \mathrm{C}$ overnight. After lyophilization, we dissolved the purified skin GAGs in $1.5 \mathrm{ml}$ deionized water for HPLC analysis. We treated $10 \mu$ of samples with $7 \mathrm{mU}$ of chondroitin ABC lyase (Sigma Aldrich, Taufkirchen, Germany) in $50 \mu \mathrm{l}$ of $100 \mathrm{mM}$ Tris $/ 150 \mathrm{mM}$ sodium acetate buffer $\mathrm{pH} 8.0$ at $37^{\circ} \mathrm{C}$ for $16 \mathrm{~h}$. The reaction was blocked by boiling the solution for $1 \mathrm{~min}$. We analyzed the unsaturated 
disaccharides generated from hyaluronan (HA; $\triangle$ diHA) and dermatan/chondroitin sulfate (DS/CS; $\Delta$ di4s and $\Delta$ di6s) after enzymatic treatment of the purified GAGs using HPLC-MS in selective ion mode according to previous literature data (Gill et al. 2012). HPLC analysis was performed by an Agilent 1260 Infinity LC system in conjunction with an Agilent 6460 triple-quadrupole mass spectrometer (Waldbroon, Germany). Chromatography was carried out using a porous graphitized carbon column (Hypercarb, Hypercarb Column, $5 \mu \mathrm{m}, 100 \mathrm{~mm} \times 4.6 \mathrm{~mm}$ ) purchased from Thermo Scientific (Waltham, MA). For the separation gradient elution program was used: Solvent A was $0.1 \%$ formic acid adjusted to $\mathrm{pH} 5.5$ by ammonia and solvent $\mathrm{B}$ was solvent $\mathrm{A}$ in $90 \%$ acetonitrile. The gradient used was $0-15 \% \mathrm{~B}$ in 4 min and $15 \% \mathrm{~B}$ over 50 min. Standards of Hyaluronic acid (H9649-1MG) and Chondroitin-4,6-sulfate (CD004) were purchased from Sigma Aldrich (USA) and Iduron (Manchester, UK) respectively.

\section{Quantitative Real-Time PCR}

Total RNA was isolated from the skin tissue samples by Geneaid Total RNA Mini Kit (Geneaid, New Taipei, Taiwan), according to the manufacturer's instructions. $100 \mu \mathrm{g}$ of total RNA was reverse-transcribed and VEGF-A and VEGF-C mRNA expressions were determined by real-time polymerase chain reaction (PCR) on LightCycler 480 (Roche Diagnostics, Mannheim, Germany).

For quantitative PCR the following primer pairs were applied: VEGF-A forward: 5'-GTG CAC TGG ACC CTG GCT TTA C-3'; VEGF-A reverse: 5'-TTT TCT GGC TTT GTT CTA TCT TTC-3'; VEGF-C forward: 5'-TCC ACC ATC AAA CAT GCA GC-3'; VEGF-C reverse: 5'-TCA GTC GAT TTG TAC ATG GTC GT-3'; GAPDH forward: 5'-GGT GAA GGT CGG AGT CAA CG-3'; GAPDH reverse: 5'-CAA AGT TGT CAT GGA TGA CC-3'.

The specificity of the PCR products was verified by the analysis of melting curves and by electrophoretic separation of the products on $2.5 \%$ agarose gel followed by staining with ethidium bromide. The $2^{-\Delta \Delta C T}$ value (relative fold change) was calculated.

\section{Results}

\section{Skin sodium concentration and dietary $\mathrm{NaCl}$ intake}

Skin sodium content in each group reflected the levels of dietary sodium intake is shown in Figure 1. In Experiment $1 \mathrm{Na}^{+}$content of the skin in group HSD
$(1.334 \pm 0.022 \mathrm{mg} / \mathrm{g} ; 116 \%)$ showed an elevated level compared to group LSD $(1.148 \pm 0.075 \mathrm{mg} / \mathrm{g} ; 100 \%$; $\mathrm{p}=0.05$ ), whereas group HSD/LSD showed an intermediate value $(1.192 \pm 0.051 \mathrm{mg} / \mathrm{g} ; 104 \% ; \mathrm{p}>0.05)$. The same tendencies were observed in Experiment 2: (LSD: $0.974 \pm 0.069 \mathrm{mg} / \mathrm{g} ; 100 \%$ vs. HSD: $1.158 \pm 0.084 \mathrm{mg} / \mathrm{g}$; $118 \%$; $\mathrm{p}=0.0001$ ).

Since the homeostasis of $\mathrm{Na}^{+}$and $\mathrm{K}^{+}$are closely related, we investigated the $\mathrm{K}^{+}$content of skin samples. The levels of skin $\mathrm{K}^{+}$changed in the opposite direction compared to skin $\mathrm{Na}^{+}$: LSD $1.205 \pm 0.197 \mathrm{mg} / \mathrm{g}(100 \%)$, HSD $\quad 1.001 \pm 0.155 \mathrm{mg} / \mathrm{g} \quad(83 \%), \quad$ HSD/LSD $1.092 \pm$ $0.020 \mathrm{mg} / \mathrm{g}(90.5 \%)$. Although the absolute amount of $\mathrm{K}^{+}$showed differences between groups, intergroup comparison failed to reach significance: HSD vs. LSD $\mathrm{p}>0.05 ; \mathrm{HSD} / \mathrm{LSD}$ vs. HSD $\mathrm{p}>0.05$ ).

We obtained similar, although statistically not significant $(\mathrm{p}<0.07)$ result in Experiment 2: LSD: $1.059 \pm 0.133 \mathrm{mg} / \mathrm{g}(100 \%)$ vs. HSD $0.975 \pm 0.071 \mathrm{mg} / \mathrm{g}$ $(92 \%)$. Parallel with increased sodium intake, differences in sodium excreted in urine were detected in Experiment 1: $\mathrm{LSD}=97.6 \pm 62.78 \mathrm{mmol} / \mathrm{l} \quad(100 \%), \quad \mathrm{HSD}=172.75 \pm$ $32.15 \mathrm{mmol} / 1 \quad(172 \%), \mathrm{HSD} / \mathrm{LSD}=40.1 \pm 12.029 \mathrm{mmol} / 1$ (41\%); (HSD vs. LSD $\mathrm{p}>0.05$; HSD vs. HSD/LSD $\mathrm{p}<0.001) . \quad$ In $\quad$ Experiment $2: \quad H S D=69.0 \pm 29.8 \mathrm{mmol} / 1$ $(100 \%), \mathrm{LSD}=21.3 \pm 7.5 \mathrm{mmol} / \mathrm{l}(30.86 \%)(\mathrm{p}<0.01)$.

In order to rule out the possibility that $\mathrm{Na}^{+}$overload in the skin is a consequence of kidney malfunction, we monitored the blood creatinine and urea levels at the end of each experiment. Since blood creatinine and urea levels as well as blood sodium levels in all experiments remained in the normal physiologic range for rats (creatinine: 20.5-40.6 $\mu \mathrm{mol} / \mathrm{ml}$; urea: 4.5-8.96 $\mu \mathrm{mol} / \mathrm{ml}$; sodium $120-145 \mathrm{mmol} / \mathrm{l}$ ) (data not shown) we concluded that the extremes in skin sodium content are the direct consequence of dietary manipulations.

\section{Excess $\mathrm{Na}+, \mathrm{K}+$ and water storage in the skin}

In Experiment $25.6 \%$ difference in skin water content $(\mathrm{m} / \mathrm{m})$ between HSD and LSD was measured (HSD $=60.4 \pm 4.043 \% \quad$ vs. $\quad$ LSD $=54.79 \pm 4.055 \%$; $\mathrm{p}=0.0025$ ). The difference between skin ion and water content holds important information about the level of osmotically inactive sodium storage. Therefore, from the $\mathrm{Na}^{+}, \mathrm{K}^{+}$, and water content of the skin $\mathrm{a}\left(\left[\mathrm{Na}^{+}+\mathrm{K}^{+}\right] /\right.$water $)$quotient was calculated:

$\left[\mathrm{Na}^{+}\right](\mathrm{mmol}$, dry skin $)+\left[\mathrm{K}^{+}\right]($mmol, dry skin $) /$ $\mathrm{ml}$ of water in wet skin 

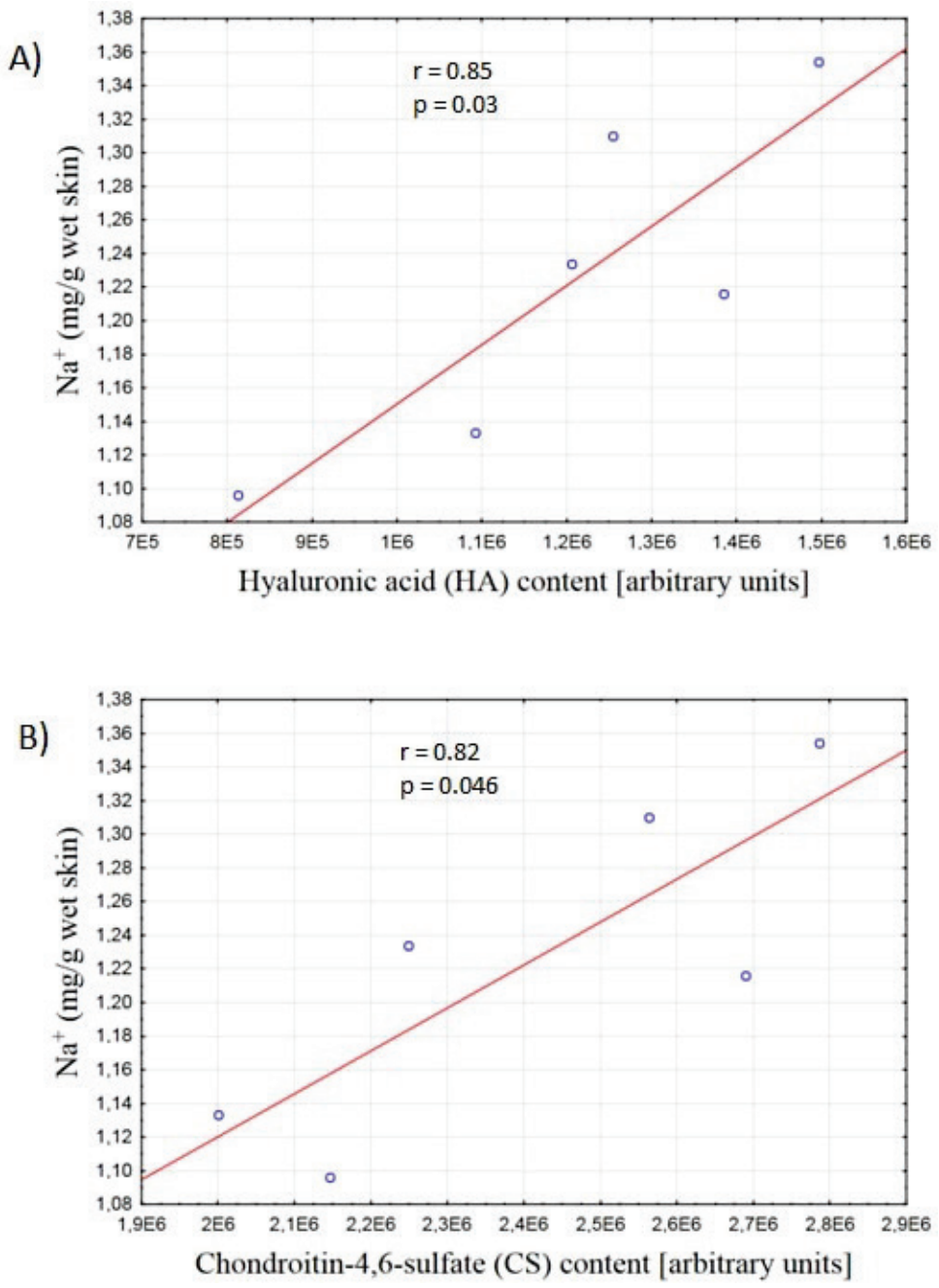

Fig. 1. Correlation graphs showing significant and strong correlation between skin $\mathrm{Na}^{+}$and skin $\mathrm{HA}$ (A) and skin $\mathrm{Na}^{+}$and skin CS (B) content in animals with different levels of dietary sodium intake (Experiment $1, n=6$ ).
The $\left(\left[\mathrm{Na}^{+}+\mathrm{K}^{+}\right] /\right.$water $)$quotient calculated from the respective data shows no significant difference between the two dietary groups: $(\mathrm{LSD}=0.126 \pm 0.001 \mathrm{mmol} / \mathrm{ml}$ vs. $\mathrm{HSD}=0.124 \pm 0.006 \mathrm{mmol} / \mathrm{ml} ; \mathrm{p}=0.51)$.

The changes in the $\mathrm{Na}^{+}$content of the skin were consistently counterbalanced by changes in skin $\mathrm{K}^{+}$content leaving the $\left(\left[\mathrm{Na}^{+}+\mathrm{K}^{+}\right] /\right.$water $)$quotient between the two dietary groups unchanged. No difference was found in body weight between the two dietary groups in Experiment 2 (LSD $107.89 \%$ vs. HSD $107.84 \%$, $\mathrm{p}=0.98)$.

\section{Relationship between skin $\mathrm{Na}+$ and skin GAG levels}

Measurement of skin GAG content showed significant differences between dietary groups. Experiment 1: Hyaluronic acid: $\mathrm{HSD}=100 \%$, $\mathrm{LSD}=76.9 \%(\mathrm{p}<0.01), \mathrm{HSD} / \mathrm{LSD}=87.5 \%$; $<<0.01 ; \mathrm{HSD}$ vs. $\quad H S D / L S D \quad p=0.096 ; \quad$ Chondroitin-4,6-sulfate: $\mathrm{HSD}=100 \%, \mathrm{LSD}=82.7 \%(\mathrm{p}<0.01), \mathrm{HSD} / \mathrm{LSD} 87.4 \%$ $(\mathrm{p}<0.053)$ (data expressed as means of groups; arbitrary units).
The same tendencies were observed in Experiment 2: hyaluronic acid: $\mathrm{HSD}=100 \%$, LSD $=64.5 \% \quad(p<0.0001) ; \quad$ Chondroitin-4,6-sulfate: $\mathrm{HSD}=100 \%, \quad \mathrm{LSD}=75.6 \% \quad(\mathrm{p}<0.0001)$. We observed parallel changes in skin $\mathrm{Na}^{+}$and GAG content: the levels of both GAGs raised in the high salt group, decreased in the low salt group, and showed an intermediate level in the group switched back from high salt to low salt diet. A coefficient, calculated from the respective data shows significant positive correlation between skin GAGs and skin $\mathrm{Na}^{+}$content: $\mathrm{Na}^{+}$-hyaluronic acid $(\mathrm{r}=0.85, \mathrm{p}=0.03)$; $\mathrm{Na}^{+}$-chondroitin-4,6-sulfate $(\mathrm{r}=0.82, \mathrm{p}=0.046)$.

\section{Relationship of skin GAG content to VEGF-C and VEGF-A}

In Experiment 1 parallel with a $30 \%$ increase in hyaluronic acid and $20 \%$ in Chondroitin-4,6-sulfate content, mRNA levels of VEGF-C were also higher in group HSD (138.9 \%) compared to group LSD (100\%) suggesting the GAG synthetizing role of VGF-C (HSD vs. $\operatorname{LSD} \mathrm{p}=0.492$ ). 
Similar tendencies were observed in Experiment 2: Hyaluronic acid $\mathrm{LSD}=100 \%$, Hyaluronic acid $\mathrm{HSD}=152.9 \% ; \quad(\mathrm{p}<0.0001)$ Chondroitin-4,6-sulfate $\mathrm{LSD}=100 \%$, Chondroitin-4,6-sulfate $\mathrm{HSD}=132.2 \%$ $(\mathrm{p}<0.0001)$; VEGF-C mRNA expressions $\mathrm{LSD}=100 \%$, $\mathrm{HSD}=151.2 \% \quad(\mathrm{p}=0.07)$. Interestingly, no significant differences in the expression levels of VEGF-A were found in groups with different sodium intake. It slightly increased in both the $\mathrm{LSD}(\mathrm{HSD}=100 \%, \mathrm{LSD}=112 \%$, $\mathrm{p}>0.05)$ and the HSD/LSD groups $(122 \%, \mathrm{p}>0.05)$; HSD vs. HSD/LSD, $\mathrm{p}>0.05$.

Since changes in mRNA levels happen over a shorter time course it was reasonable to examine VEGF-A mRNA levels at an earlier time point (i.e. $72 \mathrm{~h}$ after the change in sodium intake). Similarly to Experiment 1, when comparing the VEGF-A mRNA levels of group HSD/LSD (in Experiment 3) to the mRNA level of group HSD (Experiment 2) no significant difference was observed (HSD 2 $=100 \%$ vs. HSD/LSD $3=84 \% ; p=0.65$ ). Changes in skin electrolyte and water content, skin GAG content and the mRNA expression levels of VEGF-A and VEGF-C in the experimental animals are summarized in Table 2.

Table 2. Changes in skin electrolyte and water content, skin GAG content and the mRNA expression levels of VEGF-A and VEGF-C in animals receiving different levels of dietary sodium intake.

\begin{tabular}{|c|c|c|c|c|c|}
\hline & LSD & HSD & HSD/LSD & LSD & HSD \\
\hline & & Experiment 1 & & \multicolumn{2}{|c|}{ Experiment 2} \\
\hline Skin $\mathrm{Na}^{+}(\mathrm{mg} / \mathrm{g})$ & $1.148 \pm 0.075$ & $1.334 \pm 0.022^{* \#}$ & $1.192 \pm 0.051$ & $0.974 \pm 0.069$ & $1.158 \pm 0.084^{*}$ \\
\hline Skin $K^{+}(m g / g)$ & $1.205 \pm 0.197$ & $1.001 \pm 0.155$ & $1.092 \pm 0.020$ & $1.059 \pm 0.133$ & $0.975 \pm 0.071$ \\
\hline $\begin{array}{l}\text { Skin water content } \\
(\%)\end{array}$ & & & & $54.799 \pm 4.055$ & $60.440 \pm 4.043^{*}$ \\
\hline$\left[\mathrm{Na}^{+}+\mathrm{K}^{+}\right]$ & & & & & \\
\hline $\begin{array}{l}\text { concentration in } \\
\text { skin water (mmol/l) }\end{array}$ & & & & $0.126 \pm 0.011$ & $0.124 \pm 0.006$ \\
\hline $\begin{array}{l}\text { Skin } H A \\
\text { content }[A U]\end{array}$ & $1,104,451 \pm 170,395$ & $1,435,126 \pm 119,425^{*}$ & $1,256,268 \pm 117,728$ & $287,552 \pm 57,567$ & $187,598 \pm 38,753^{*}$ \\
\hline $\begin{array}{l}\text { Skin } C S \\
\text { content }[A U]\end{array}$ & $2,326,461 \pm 165,196$ & $2,787,854 \pm 249,106^{*}$ & $2,459,153 \pm 241661$ & $500,518 \pm 40,921$ & $371,565 \pm 55,539 *$ \\
\hline $\begin{array}{l}\text { Skin } V E G F-A \\
m R N A \text { content }[A U]\end{array}$ & $1.123 \pm 1.072$ & $0.999 \pm 1.008$ & $1.224 \pm 0.639$ & $1.098 \pm 0.577$ & $0.879 \pm 0.409$ \\
\hline $\begin{array}{l}\text { Skin VEGF-C } \\
m R N A \text { content }[A U]\end{array}$ & $0.720 \pm 0.450$ & $1.001 \pm 0.421$ & $0.850 \pm 0.530$ & $0.542 \pm 0.381$ & $0.820 \pm 0.467$ \\
\hline Urine $\mathrm{Na}^{+}(\mathrm{mmol} / \mathrm{l})$ & $97.625 \pm 62.781$ & $172.75 \pm 32.15^{\#}$ & $40.125 \pm 12.029$ & $21.300 \pm 7.500$ & $69.000 \pm 29.800^{*}$ \\
\hline Body mass (\%) & & & & $107.890 \pm 5.950$ & $107.840 \pm 6.390$ \\
\hline $\begin{array}{l}\text { MAP (Week 4) } \\
(\mathrm{mm} \mathrm{Hg)}\end{array}$ & & & & $102 \pm 19$ & $98 \pm 13$ \\
\hline
\end{tabular}

$\mathrm{LSD}=$ low salt diet (4 weeks), HSD=high salt diet (4 weeks), HSD/LSD=high salt diet (4 weeks) followed by low salt diet (4 weeks). $*=p<0.05$ vs. LSD; ${ }^{*}=p<0.05$ vs. HSD/LSD.

\section{Discussion}

In the present study the impact of dietary sodium intake on the skin sodium and GAG content (Hyaluronic acid, Chondroitin sulfate), as well as on the expression of VEGF-A, VEGF-C mRNA was investigated in a rat model. Significant positive relationship was found between sodium intake, skin sodium and skin GAG content. Moreover, experimental evidences were provided for the involvement of VEGF-C in GAG metabolism, but no association was documented between VEGF-A and GAG. It is suggested that some of the excess sodium is bound to GAGs and stored in osmotically inactive form in the skin but the regulatory role of VEGFs in this process remained to be explored.

Earlier studies have pointed out the $\mathrm{Na}^{+}$-binding ability of skin interstitial GAGs and the change in their amount followed by different levels of dietary sodium 
intake. Sulyok and colleagues (Sulyok 2013) revealed that ECM-bound water consists of fractions (Ling 1992) with different mobility and composition (tightly bound, loosely bound and free), although they could not establish a clear relationship between GAG (hyaluronan) and bound water fraction. The pioneering experiments of Titze et al. (2002) on the hyperplasia of the lymph capillary network induced by dietary sodium overload explains the mechanism by which excess interstitial fluid is temporarily stored and drained back to the circulation (Marvar et al. 2009).

Since the sodium and volume buffering capacity of this system is supposed to be limited, a regulating mechanism is essential in order to liberate excess interstitial fluid from GAGs and drain it back to the circulation for clearance by the kidney.

Despite intensive research in this area, mechanism governing polymerization and depolymerization of GAGs is still elusive. For the phenomenon of regulated synthesis and degradation of GAGs, we found evidence in a 2013 issue of American Journal of Pathology. (Foster et al. 2013) and his research group provided evidences that the two isoforms of Vascular Endothelial Growth Factor, VEGF-A and VEGF-C influences the amount and charge density of the glycocalyx of conditionally immortalized glomerular endothelial cells of the kidney podocytes. In the kidney, these cells are constituents of the glomerular filtration barrier and are presumedly involved in the fine tuning of the filtering function of kidney podocytes. In their experimental setting, they proved that cultured cells can synthetize GAG molecules and are able to secrete them to the cell surface. They observed that VEGF-C significantly increased the negative charge density of the glycocalyx of GENC cells. VEGF-C was also able to intensify the production and secretion of negatively charged hyaluronic acid molecules. They also observed that VEGF-A does not affect the charge properties of negatively charged GAGs but instead promotes their detachment into the culture media.

Our attempt in establishing causal relationship between sodium intake, skin GAG content and the two isoforms of VEGF has brought only partial success: GAG concentration in the skin showed strong and significant correlation with the amount of dietary $\mathrm{Na}^{+}$intake. The decrease in GAG content after switch from high salt diet to low salt diet renders the regulated degradation of GAGs possible. The tendencies in the levels of VEGF-C also fits in this conception: increased VEGF-C levels are likely to reflect the organism's need for extra sodium binding capacity. Although not reaching the desired level of significance, there is a tendency pointing toward the possible role of VEGF-C in the synthesis of skin interstitial GAGs. Selective blockade of VEGF-C in salt overloaded animals would give further evidence for the causal role of VEGF-C in GAG homeostasis.

Based on the documented GAG-degrading effect (Foster et al. 2013) of VEGF-A, we expected elevated levels of VEGF-A in group HSD/LSD. Contrary to our expectations, no significant differences in the expression levels of VEGF-A were found in group HSD/LSD: $\mathrm{HSD}=100 \%, \mathrm{LSD}=112 \%, \mathrm{HSD} / \mathrm{LSD}=122 \%$ (HSD vs. LSD $p>0.05$; HSD vs. HSD/LSD $p>0.05$ ). Since changes in mRNA levels happen over a shorter time course it was reasonable to examine VEGF-A mRNA levels at an earlier time point (i.e. $72 \mathrm{~h}$ after the change in sodium intake). Similarly to Experiment 1, when comparing the VEGF-A mRNA levels of group HSD/LSD (in Experiment 3) to the mRNA level of group HSD (Experiment 2) no significant difference was observed (HSD $2=100 \%$ vs. HSD/LSD 3=84 \%; $\mathrm{p}=0.65$ )

Having used normotensive, salt resistant Wistar rats, the lack of difference in blood pressure between HSD and LSD groups can be attributed to the properly functioning regulating mechanisms including the kidney the cardiovascular system and - presumably - the skin. However, since we did not block the regulating mechanism of the skin (unlike in the experiment of Titze et al. (2009)), the absence of the rise in blood pressure can only be considered as an indirect evidence of its role played in blood pressure regulation.

As in our study the regulatory role of VEGFs in the control of GAGs-sodium interaction remained inconclusive further experiments are to be conducted to explore: a) the time course of the response pattern of VEGF-A/VEGF-C mRNA and protein expression to manipulation of sodium intake, b) the effect of anti-VEGF therapy to the sodium-GAG-VEGF interplay and c) the possible contribution of hormones/hormonelike factors that are known to be involved in the synthesis and degradation of GAGs in various tissues needs also to be assessed.

\section{Conflict of Interest}

There is no conflict of interest.

\section{Acknowledgements}

This study was supported by the OTKA K108688 grant. 


\section{References}

CHEN MJ, HSIEH YT, WENG YM, CHIOU RYY: Flame photometric determination of salinity in processed foods. Food Chem 91: 765-770, 2005.

DAHLMANN A, DORFELT K, EICHER F, LINZ P, KOPP C, MOSSINGER I, HORN S, BUSCHGES-SERAPHIN B, WABEL P, HAMMON M, CAVALLARO A, ECKARDT KU, KOTANKO P, LEVIN NW, JOHANNES B, UDER M, LUFT FC, MÜLLER DN, TITZE JM: Magnetic resonance-determined sodium removal from tissue stores in hemodialysis patients. Kidney Int 87: 434-441, 2015.

DIPIETRO ES, BASHOR MM, STROUD PE, SMARR BJ, BURGESS BJ, TURNER WE, NEESE JW: Comparison of an inductively coupled plasma atomic emission-spectrometry method for the determination of calcium, magnesium, sodium, potassium, copper and zinc with atomic-absorption spectroscopy and flame photometry methods. Sci Total Environ 74: 249-262, 1988.

FARBER SJ, SCHUBERT M, SCHUSTER N: The binding of cations by chondroitin sulfate. $J$ Clin Invest 36: 1715-1722, 1957.

FOSTER RR, ARMSTRONG L, BAKER S, WONG DW, WYLIE EC, RAMNATH R, JENKINS R, SINGH A, STEADMAN R, WELSH GI, MATHIESON PW, SATCHELL SC: Glycosaminoglycan regulation by VEGFA and VEGFC of the glomerular microvascular endothelial cell glycocalyx in vitro. Am J Pathol 183: 604-616, 2013.

GILL VL, WANG Q, SHI X, ZAIA J: Mass spectrometric method for determining the uronic acid epimerization in heparan sulfate disaccharides generated using nitrous acid. Anal Chem 84: 7539-7546, 2012.

HEER M, BAISCH F, KROPP J, GERZER R, DRUMMER C: High dietary sodium chloride consumption may not induce body fluid retention in humans. Am J Physiol Renal Physiol 278: F585-F595, 2000.

HEER M, FRINGS-MEUTHEN P, TITZE J, BOSCHMANN M, FRISCH S, BAECKER N, BECK L: Increasing sodium intake from a previous low or high intake affects water, electrolyte and acid-base balance differently. Br J Nutr 101: 1286-1294, 2009.

KOPP C, LINZ P, DAHLMANN A, HAMMON M, JANTSCH J, MULLER DN, SCHMIEDER RE, CAVALLARO A, ECKARDT KU, UDER M, LUFT FC, TITZE J: 23Na magnetic resonance imaging-determined tissue sodium in healthy subjects and hypertensive patients. Hypertension 61: 635-640, 2013.

KOPP C, LINZ P, WACHSMUTH L, DAHLMANN A, HORBACH T, SCHOFL C, RENZ W, SANTORO D, NIENDORF T, MULLER DN, NEININGER M, CAVALLARO A, ECKARDT KU, SCHMIEDER RE, LUFT FC, UDER M, TITZE J: (23)Na magnetic resonance imaging of tissue sodium. Hypertension 59: 167-172, 2012.

LING GN: A Revolution in the Physiology of the Living Cell. Krieger Publishing Company, Malabar, 1992, 378 p.

LINZ P, SANTORO D, RENZ W, RIEGER J, RUEHLE A, RUFF J, DEIMLING M, RAKOVA N, MULLER DN, LUFT FC, TITZE J, NIENDORF T: Skin sodium measured with ${ }^{23} \mathrm{Na}$ MRI at 7.0 T. NMR Biomed 28: 54-62, 2015.

MACHNIK A, NEUHOFER W, JANTSCH J, DAHLMANN A, TAMMELA T, MACHURA K, PARK JK, BECK FX, MULLER DN, DERER W, GOSS J, ZIOMBER A, DIETSCH P, WAGNER H, VAN ROOIJEN N, KURTZ A, HILGERS KF, ALITALO K, ECKARDT KU, LUFT FC, KERJASCHKI D, TITZE J: Macrophages regulate salt-dependent volume and blood pressure by a vascular endothelial growth factor-C-dependent buffering mechanism. Nat Med 15: 545-552, 2009.

MARVAR PJ, GORDON FJ, HARRISON DG: Blood pressure control: salt gets under your skin. Nat Med 15: 487-488, 2009.

PALACIOS C, WIGERTZ K, MARTIN BR, JACKMAN L, PRATT JH, PEACOCK M, MCCABE G, WEAVER CM: Sodium retention in black and white female adolescents in response to salt intake. J Clin Endocrinol Metab 89: 1858-1863, 2004.

SCHAFFLHUBER M, VOLPI N, DAHLMANN A, HILGERS KF, MACCARI F, DIETSCH P, WAGNER H, LUFT FC, ECKARDT KU, TITZE J: Mobilization of osmotically inactive $\mathrm{Na}+$ by growth and by dietary salt restriction in rats. Am J Physiol Renal Physiol 292: F1490-F1500, 2007. 
SEELIGER E, LADWIG M, REINHARDT HW: Are large amounts of sodium stored in an osmotically inactive form during sodium retention? Balance studies in freely moving dogs. Am J Physiol Regul Integr Comp Physiol 290: R1429-R1435, 2006.

SULYOK E: Physical water compartments: a revised concept of perinatal body water physiology. Physiol Res 55: 133-138, 2006.

SULYOK E: Some clinical aspects of sodium homeostasis disorders. (In Hungarian) Orv Hetil 154: 1488-1497, 2013.

TITZE J, KRAUSE H, HECHT H, DIETSCH P, RITTWEGER J, LANG R, KIRSCH KA, HILGERS KF: Reduced osmotically inactive Na storage capacity and hypertension in the Dahl model. Am J Physiol Renal Physiol 283: F134-F141, 2002a.

TITZE J, LANG R, ILIES C, SCHWIND KH, KIRSCH KA, DIETSCH P, LUFT FC, HILGERS KF: Osmotically inactive skin $\mathrm{Na}+$ storage in rats. Am J Physiol Renal Physiol 285: F1108-F1117, 2003.

TITZE J, MAILLET A, LANG R, GUNGA HC, JOHANNES B, GAUQUELIN-KOCH G, KIHM E, LARINA I, GHARIB C, KIRSCH KA: Long-term sodium balance in humans in a terrestrial space station simulation study. Am J Kidney Dis 40: 508-516, $2002 \mathrm{~b}$.

TITZE J, SHAKIBAEI M, SCHAFFLHUBER M, SCHULZE-TANZIL G, PORST M, SCHWIND KH, DIETSCH P, HILGERS KF: Glycosaminoglycan polymerization may enable osmotically inactive Na+ storage in the skin. Am J Physiol Heart Circ Physiol 287: H203-H208, 2004. 